\title{
The rising marriage mortality gap among Whites
}

\author{
Philip N. Cohen \\ University of Maryland, College Park \\ pnc@umd.edu \\ @) familyunequal \\ philipncohen.com
}

November 2, 2019

\begin{abstract}
Although the decline in marriage has been cited as a possible contributor to the "despair" afflicting marginalized White communities, these studies have not directly considered mortality by marital status. This paper uses complete death certificate data from the Mortality Multiple Cause Files with American Community Survey data to examine age-specific mortality rates for married and non-married people from 2007 to 2017. The overall rise in White mortality is limited almost exclusively to those who are not married, for men and women. By comparison, mortality for Blacks and Hispanics has fallen or remained flat regardless of marital status (except for young, single Hispanic men). Analysis by education level shows death rates have risen most for Whites with the lowest education, but have also increased for those with high school or some college. Because mortality has risen faster for unmarried Whites at all but the lowest education levels, there has been an increase in the marriage mortality ratio. Mortality differentials are an increasingly important component of the social hierarchy associated with marital status.
\end{abstract}

Stata code, with links to data sources, is available on the Open Science Framework at: osf.io/gtez7/.

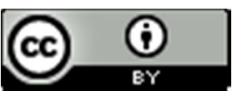

This paper and the code for this project are licensed under a Creative Commons Attribution 4.0 International License. 


\section{Introduction}

Premature adult mortality has increased among Whites in the United States (Shiels et al. 2017), and at low levels of education in particular (Bosworth 2018; Case \& Deaton 2017). This paper shows that the recent White mortality increase is disproportionately experienced by those who are not married as well as those who have less than a BA degree. I do not address the question of whether changes in family structure are contributing causally to the observed patterns of mortality; the question is important regardless of the causal relationship. Marriage is increasingly a feature of privileged life in the United States, and mortality is an important component of that pattern.

The married mortality advantage is long standing (Rendall et al. 2011). However, it appears to be growing in the U.S. Curtin and Tejada-Vera (2019) report that, over the period 2010-2017, age-adjusted death rates fell more married than for never-married people ( 7 percent versus 2 percent), while for widowed people mortality increased 6 percent and the divorced saw no change. This report expands on that analysis in several ways. First, I differentiate mortality rates by race/ethnicity and education, to address the rise in mortality for Whites with low levels of education (Case and Deaton 2017; Geronimus et al. 2019). Given widening education disparities in marital status (Cohen 2019; Lundberg et al. 2016), rising mortality may be concentrated among non-married people by virtue of group composition. Second, I examine age-specific mortality rather than age-adjusted trends. The recent trend of increased mortality is most concentrated at younger adult ages, which contributes to a wider social class gap in years of life lost to preventable causes (Bosworth 2018). Third, I use 2007 rather than 2010 as a starting point. That places the comparison before the late-2000s economic crisis, as well as before the spikes in heroin (2010) and synthetic opioid (2013) overdose deaths (Scholl et al. 2019). In addition, 2007 may be more similar to 2017 for the timing of the business cycle.

\section{Context}

Because they are concentrated among lower educated Whites, opioid overdoses account for a growing share of the mortality education gradient (Ho 2017), especially in distressed areas (Monnat 2018). Geronimus et al. (2019) argue that the "deaths of despair" narrative offered by Case and Deaton (2017) is not empirically grounded, and that the rise in opioid overdoses may not reflect cultural or social psychological crisis as much as pharmaceutical marketing and prescribing practices, the rise of dangerous new drug products, and a lack of adequate medical care. The mortality spike, in their view, may result from "high-effort coping with adversity" in response to economic uncertainty, rather than despair (Geronimus et al. 2019:224). Regardless of the interpretation, however, a wide body of research documents a steepening socioeconomic gradient in mortality, as identified by the relationship with 
income, wealth, education, occupations, or local indicators of economic dislocation (Bosworth 2018). But the role of family structure change in the trend remains uncertain. Case and Deaton (2017) discuss the decline in marriage as a likely cause of despair among Whites in downwardly mobile social or economic locations but they do not analyze mortality by marital status. The same is true of Monnat's (2018) analysis, although her spatial models predicting opioid mortality include indicators of "family distress" (the local prevalence of separated and divorced people, and single-parent families).

As the rate of college completion has increased in the last decade (U.S. Census Bureau 2019), marriage prevalence has declined. This results both from delayed entry into marriage and from nonmarriage, especially for those with lower levels of education; this is apparent in the White, non-Hispanic population (see Figure 1 below). (At the same time, divorce has decreased, but that change is concentrated among those with higher levels of education [Cohen 2019]). The decline in marriage may be an indicator of wider changes in social norms, growing uncertainty, and even despair, among Whites (Cherlin 2018; Goldman et al. 2018). However, marriage rates remain higher (and mortality lower) among Whites than among Blacks (Cohen and Pepin 2018), which suggests that the salient experience may be the rapid nature of the decline and its concentration among socially and economically marginal Whites. In any event, as we will see, the growing mortality gap between married and single Whites is a social fact. If single people are increasingly more likely to die than married people, that implies a growing marital status social hierarchy, which is important in its own right (Cohen 2018).

\section{Data and methods}

For deaths, I use complete death certificate data from the Mortality Multiple Cause Files (MMCF), produced by the National Center for Health Statistics (NCHS), for the years 2007 and 2017. For population denominators, I use the U.S. Census Bureau's American Community Survey (ACS) public use data files, as prepared by IPUMS (Ruggles et al. 2019). This is the method used in the NCHS by Curtin and Tejada-Vera (2019). With population weights, the ACS data allows estimation of population sizes by age, sex, marital status, and education level, which is necessary for this analysis.

The MMCF files yields 2,119,349 death records for White, Black, or Hispanic people ages 25-74 in 2007 and 2017, the subjects of this analysis. Marital status is available for 99.1 percent, and educational attainment is available for 96.1 percent of these death records. I code marital status as married versus not married, for calculation of a marriage mortality gap: the ratio of non-married to married agespecific mortality rates. In 2007, some states (comprising 48 percent of 2007 cases) still used an older education coding, specifying years of education instead of type of schooling and degrees completed. I 
coded these "less than high school" for 0-11 years, "high school" for 12 years, "some college" for 13-15 years, and "BA or higher" for 16 or more.

The analysis focuses on non-Hispanic Whites, for whom an increase in early adult mortality has been documented; Black and Hispanic mortality rates by age, sex, and marital status are presented for comparison. The ACS data has multiple-race coding but the death data do not. Thus, I coded Hispanics regardless of race, coded the remaining Blacks regardless of other races, and finally coded the remainder of Whites regardless of their other races. Thus, the Black sample will include those who are Black in combination with White or other races, and the White sample will include those who are White in combination other non-Black races; these are very small proportions of the Black and White samples.

\section{Results}

Figure 1 shows the change in marriage prevalence among non-Hispanic Whites by education, sex, and year, for 2007 and 2017. Marriage became less prevalent for Whites of all ages below age 70 for those with a high school degree or less, with the biggest declines apparent below age 30 and, for men, over age 60 . Among those with college degrees, declines were also concentrated below age 30, and there were only very small declines or, in the case of women, increases above age 40 . Thus marriage became more concentrated among those with more education. (See also Appendix Table 1.) 
(a) Less than high school

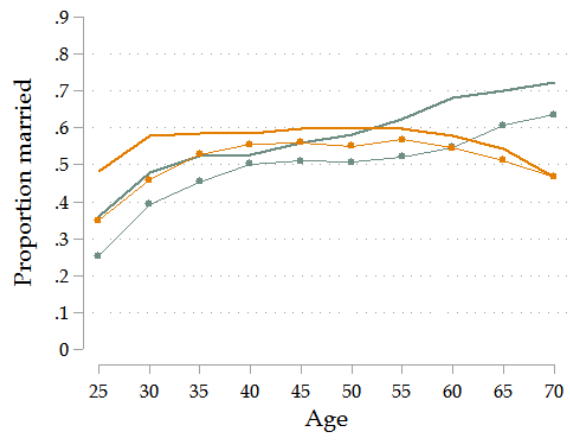

(c) Some college

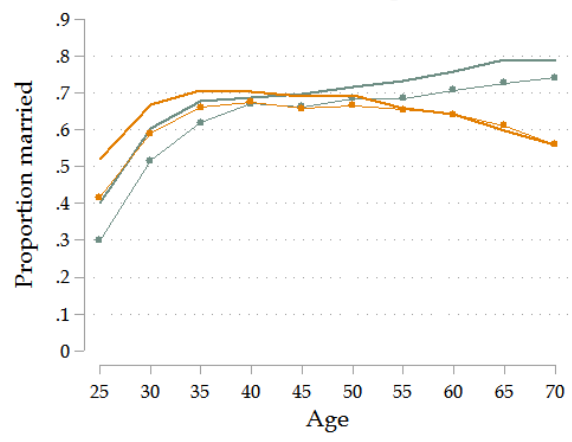

(b) High school

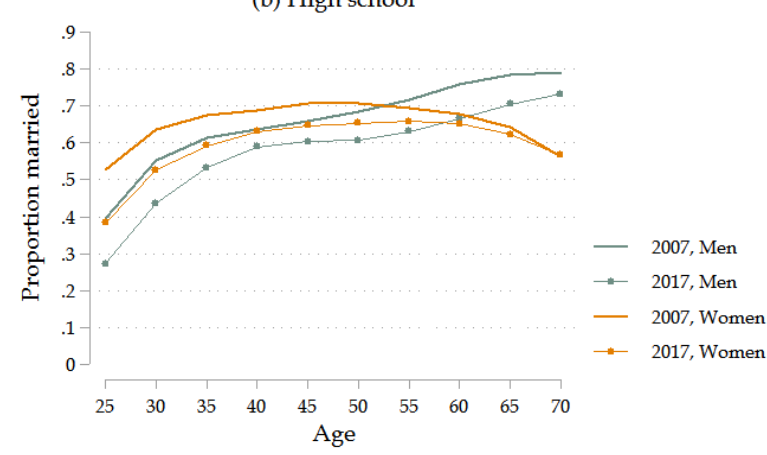

(d) BA or more

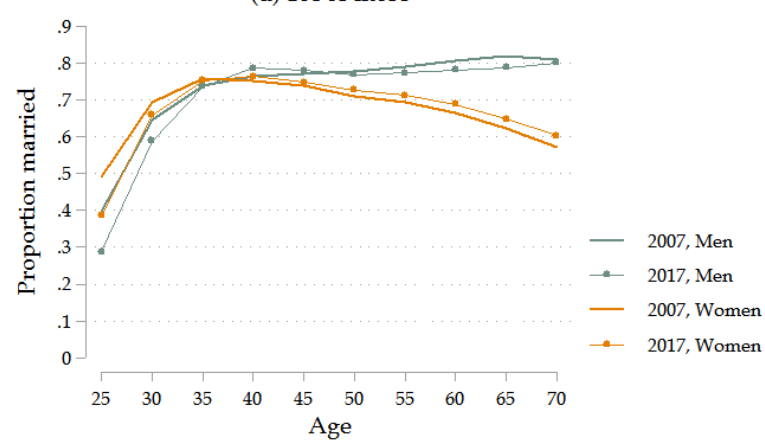

Figure 1. Proportion married among non-Hispanic Whites, by education, sex, and year

Figure 2 presents age-specific mortality rates by race/ethnicity for men (panel A) and women (panel B) for the two comparison years, 2007 and 2017. Panel C, derived from the panels above, displays the marriage mortality ratio - the ratio of single to married age-specific mortality rates - for each group and year. Rates are displayed as deaths per 10,000 population, shown on a log scale (a tabular version is in the Appendix Table 2). As the figure shows, mortality rates increased markedly for Whites, almost exclusively among those who are single. Above age 65 death rates for Whites decreased. For Hispanics and Blacks, most groups showed declining death rates or no marked change, with the exception of single Hispanic men under age 40 . The ratio of single to married death rates increased for Whites of all ages over the decade, with dramatic increases under age 40. At the most extreme, for the age range 30-34, the ratio increased from 3.0 to 3.9 for White men, and from 2.5 to 3.5 for White women. The other notable increases occurred for young Hispanic men. 
There are several other noteworthy aspects of Figure 2. First, the marriage mortality gap is higher for men than for women in all groups. This implies that either the protective effects of marriage, or the selection pressures into marriage, are stronger for men than for women. Second, the Hispanic and Black marriage mortality ratios are lower than they are for Whites. Finally, it should be emphasized that, despite marriage gaps, in all groups shown Hispanic mortality is lower than White mortality; and Black mortality in almost every case is higher than White mortality (the exceptions are small Black advantages among early adult singles).
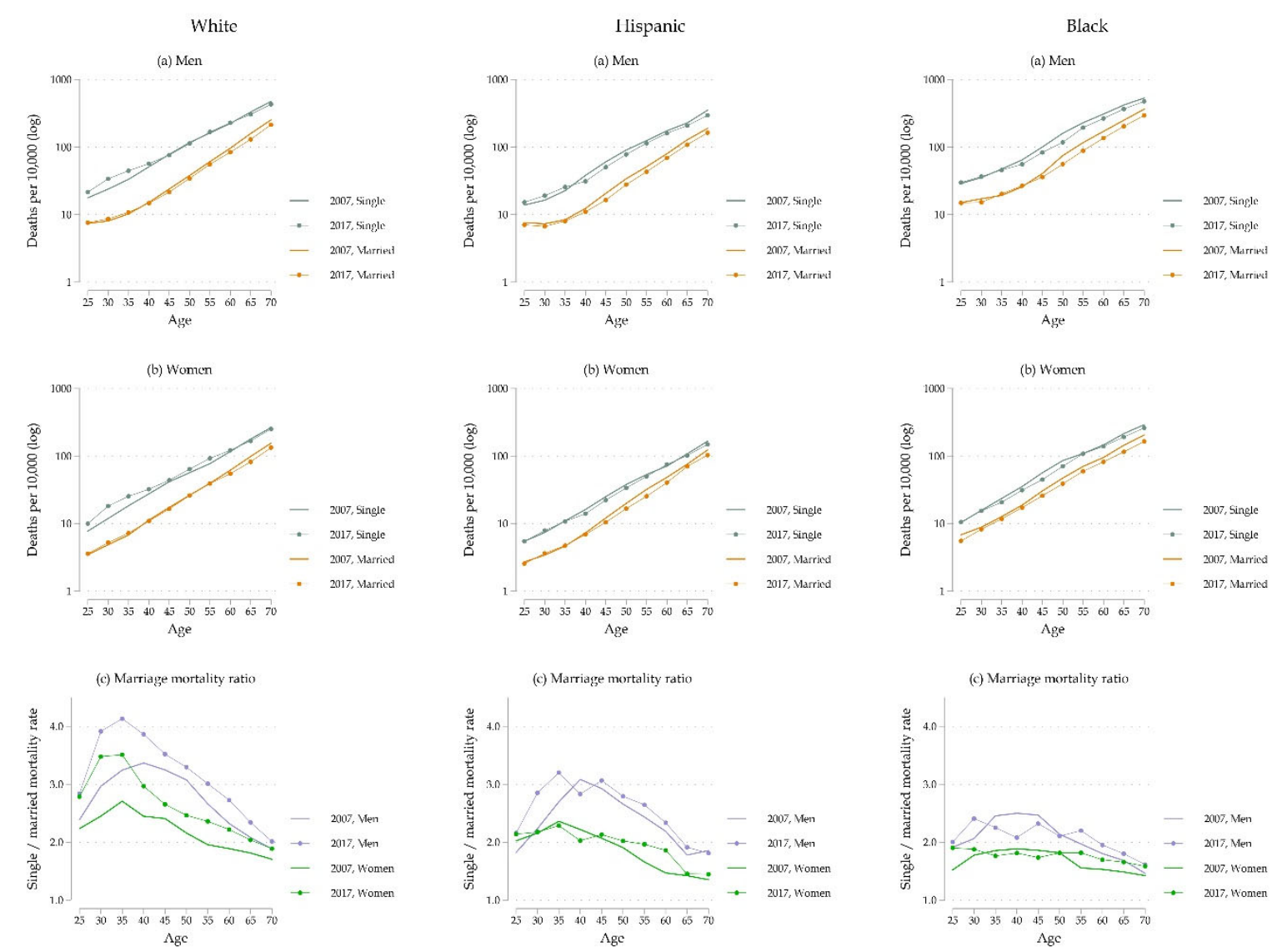

Figure 2. Age-specific mortality rates, by race/ethnicity, sex, and marital status for 2007 and 2017, with marriage mortality ratios. 
Finally, I present mortality rates for Whites only by education, sex, and marital status. If White mortality increases are concentrated among people with low levels of education, for whom marriage has become rarer, it's possible the increased White mortality among single people could reflect the greater share of that group with low education. However, Figure 3 suggests this is not the whole story (see Appendix Table 3). The first column of Figure 3, for less than high school diploma, shows that mortality has increased for both married and single Whites, such that the marriage mortality ratios are little changed. This fits an explanation in which mortality increases at the low end of education are driving the increase in the overall marriage mortality ratio. A strong mortality education gradient is clearly evident, which, all else equal, would increase the marriage mortality ratio. However, Figure 3 shows that mortality for single Whites has increased at all education levels under age 50. For single Whites with some college, deaths per 10,000 increased between 20 percent and 60 percent under age 40, or about 4 to 9 deaths per 10,000. For college graduates the increases are on the order of 1 to 4 deaths per 10,000 population. On the other hand, married mortality rates rose very little or fell at the high school level or higher (note the log scale on the figure). Thus, the marriage mortality ratios have increased in these groups. So it appears the overall White marriage mortality ratio is driven both by increasing death rates for everyone at the lowest levels of education, and by increasing marriage disparities at higher levels of education. 

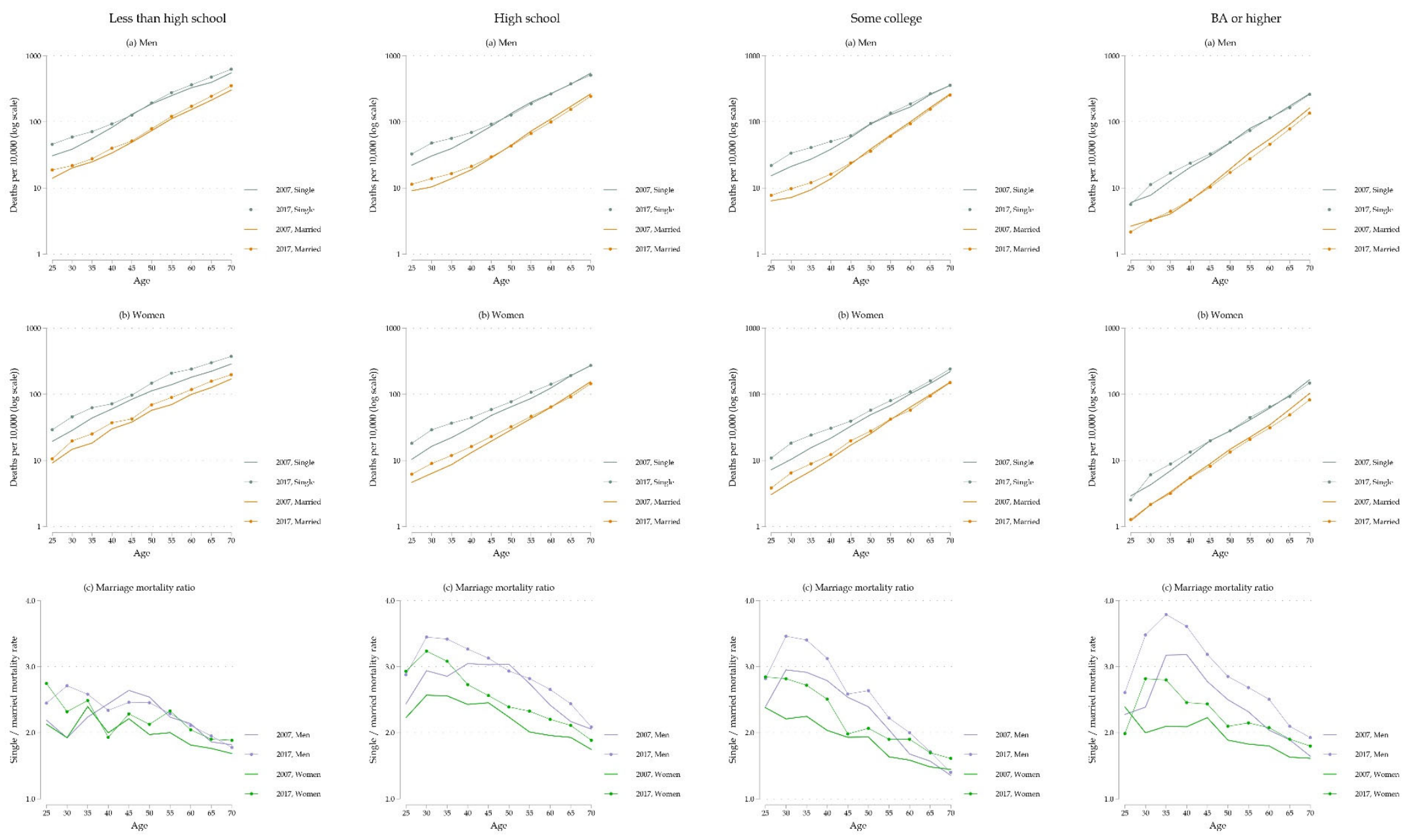

Figure 3. Age-specific mortality rates for non-Hispanic Whites, by education and sex, 2007 and 2017, with marriage mortality ratios. 


\section{Summary}

As marriage has become less prevalent in the U.S., especially among those with lower levels of education, premature mortality rates have increased for Whites. This analysis examined the extent to which the increase in mortality for Whites is concentrated among those who are not married, using NCHS national death certificate information and the ACS for population denominators, for the years 2007 and 2017.

During the period when premature White mortality jumped upward, which has been associated with the opioid epidemic, as well as alcohol-related deaths and suicide, the increases were markedly greater for those who were single, especially for those under age 40. Among 30-34 year olds, single White men are now 3.9-times more likely to die than those who are married, and the ratio is 3.5-to-1 for Women. Some of this increase may be because single people are increasingly concentrated at lower levels of education, where mortality rates are much higher. But even among those with more than a high school education, single White mortality rates rose, and the ratio of single to married mortality rates increased.

The fact that married people face lower mortality risks than those who are single is a persistent component of the status hierarchy in U.S. families, apparently representing some combination of both positive health selection into marriage and a protective effect of marriage, and this difference has long been greater for men than for women (Rendall et al. 2011). However, the recent rise in the marriage mortality ratio in the U.S. is apparent only among Whites (and to a lesser extent among young Hispanic men). And the marriage mortality ratio is considerably higher for Whites than it is for Hispanics and Blacks. 


\section{References}

Bosworth, Barry. 2018. "Increasing Disparities in Mortality by Socioeconomic Status." Annual Review of Public Health 39 (1): 237-51. https://doi.org/10.1146/annurev-publhealth-040617-014615.

Case, Anne, and Angus Deaton. 2017. "Mortality and Morbidity in the 21st Century." Brookings Papers on Economic Activity 2017: 397-476.

Cherlin, Andrew J. 2018. "Psychological Health and Socioeconomic Status among Non-Hispanic Whites." Proceedings of the National Academy of Sciences 115 (28): 7176-7178.

Cohen, Philip N. 2018. Enduring Bonds: Inequality, Marriage, Parenting, and Everything Else That Makes Families Great and Terrible. Oakland, California: University of California Press.

Cohen, Philip N. 2019. “The Coming Divorce Decline.” Socius 5 (January): 2378023119873497. https://doi.org/10.1177/2378023119873497.

Cohen, Philip N., and Joanna R. Pepin. 2018. "Unequal Marriage Markets: Sex Ratios and First Marriage among Black and White Women.” Socius 4 (January): 2378023118791084. https://doi.org/10.1177/2378023118791084.

Curtin, Sally C. and Betzaida Tejada-Vera. Mortality among adults aged 25 and over by marital status: United States, 2010-2017. NCHS Health E-Stat. 2019. https://www.cdc.gov/nchs/data/hestat/mortality/mortality_marital_status_10_17.htm.

Geronimus, Arline T., John Bound, Timothy A. Waidmann, Javier M. Rodriguez, and Brenden Timpe. 2019. "Weathering, Drugs, and Whack-a-Mole: Fundamental and Proximate Causes of Widening Educational Inequity in U.S. Life Expectancy by Sex and Race, 1990-2015." Journal of Health and Social Behavior 60 (2): 222-39. https://doi.org/10.1177/0022146519849932.

Goldman, Noreen, Dana A. Glei, and Maxine Weinstein. 2018. "Declining Mental Health among Disadvantaged Americans." Proceedings of the National Academy of Sciences 115 (28): 7290. https://doi.org/10.1073/pnas.1722023115.

Ho, Jessica Y. 2017. "The Contribution of Drug Overdose to Educational Gradients in Life Expectancy in the United States, 1992-2011." Demography 54 (3): 1175-1202. https://doi.org/10.1007/s13524-0170565-3.

Monnat, Shannon M. 2018. "Factors Associated With County-Level Differences in U.S. Drug-Related Mortality Rates." American Journal of Preventive Medicine 54 (5): 611-19. https://doi.org/10.1016/j.amepre.2018.01.040.

Rendall, Michael S., Margaret M. Weden, Melissa M. Favreault, and Hilary Waldron. 2011. "The Protective Effect of Marriage for Survival: A Review and Update.” Demography 48 (2): 481. https://doi.org/10.1007/s13524-011-0032-5.

Ruggles, Steven, Sarah Flood, Ronald Goeken, Josiah Grover, Erin Meyer, Jose Pacas and Matthew Sobek. 2019. IPUMS USA: Version 9.0. Minneapolis, MN. DOI:10.18128/D010.V9.0 


\section{Appendix tables}

\section{Table A1}

Proportion married, by year, education, sex, and age

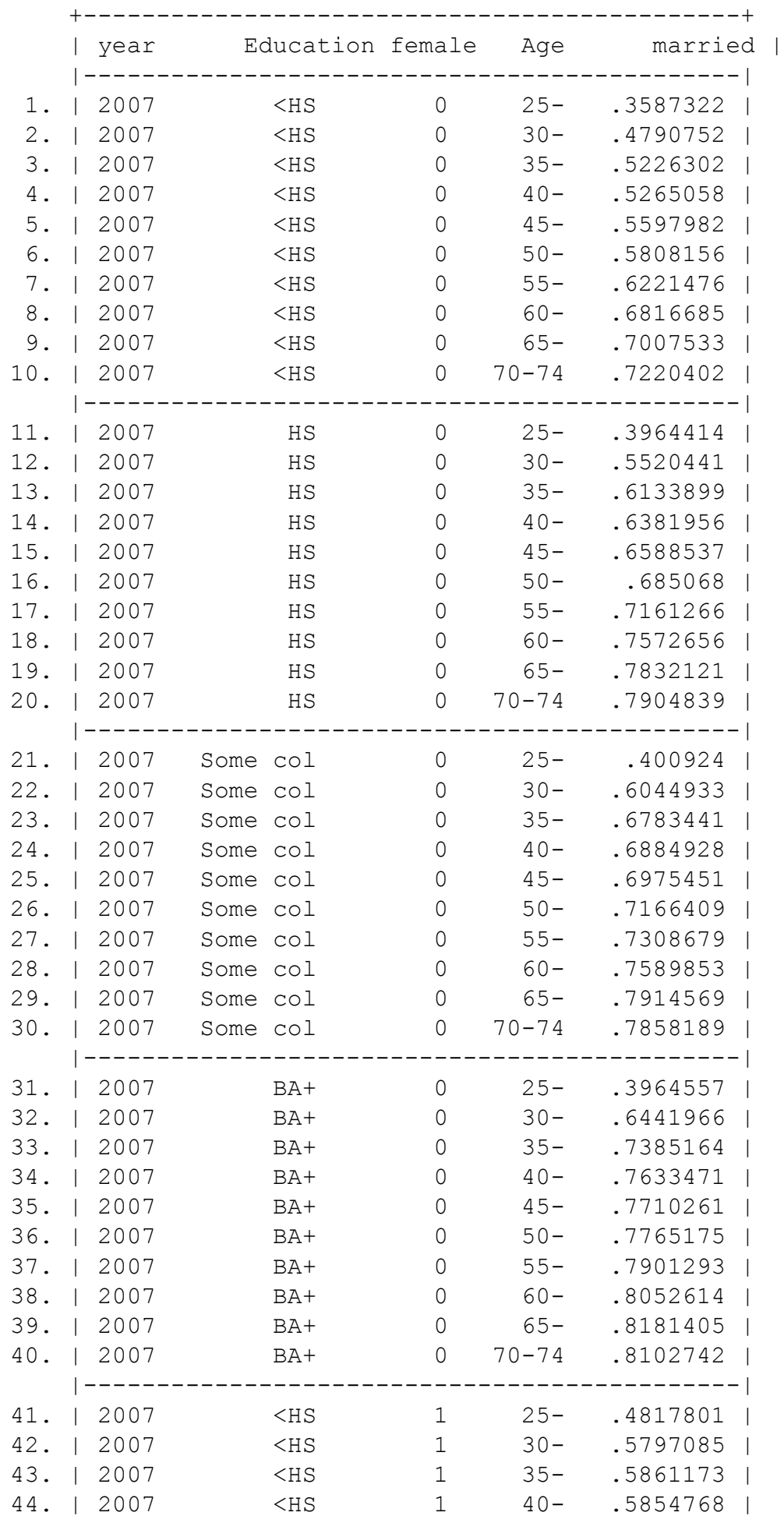




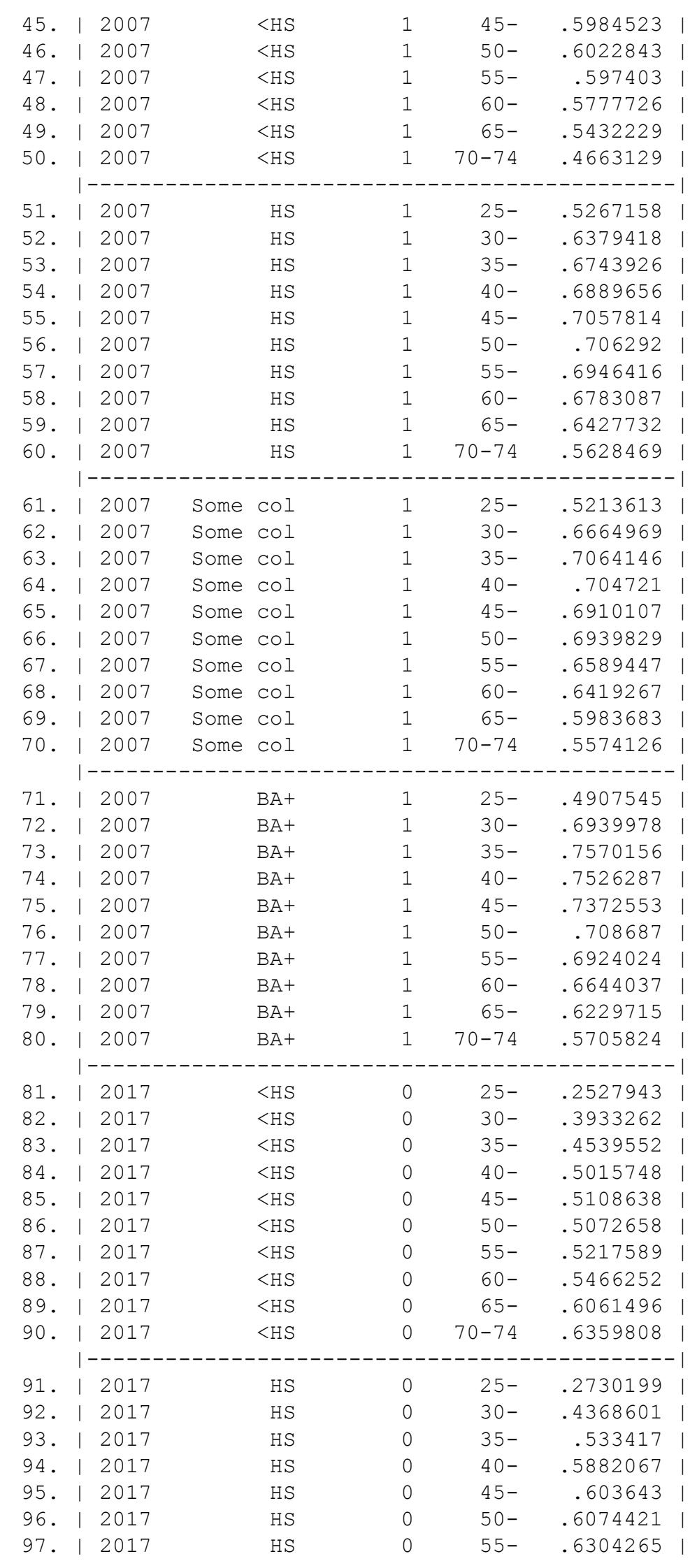




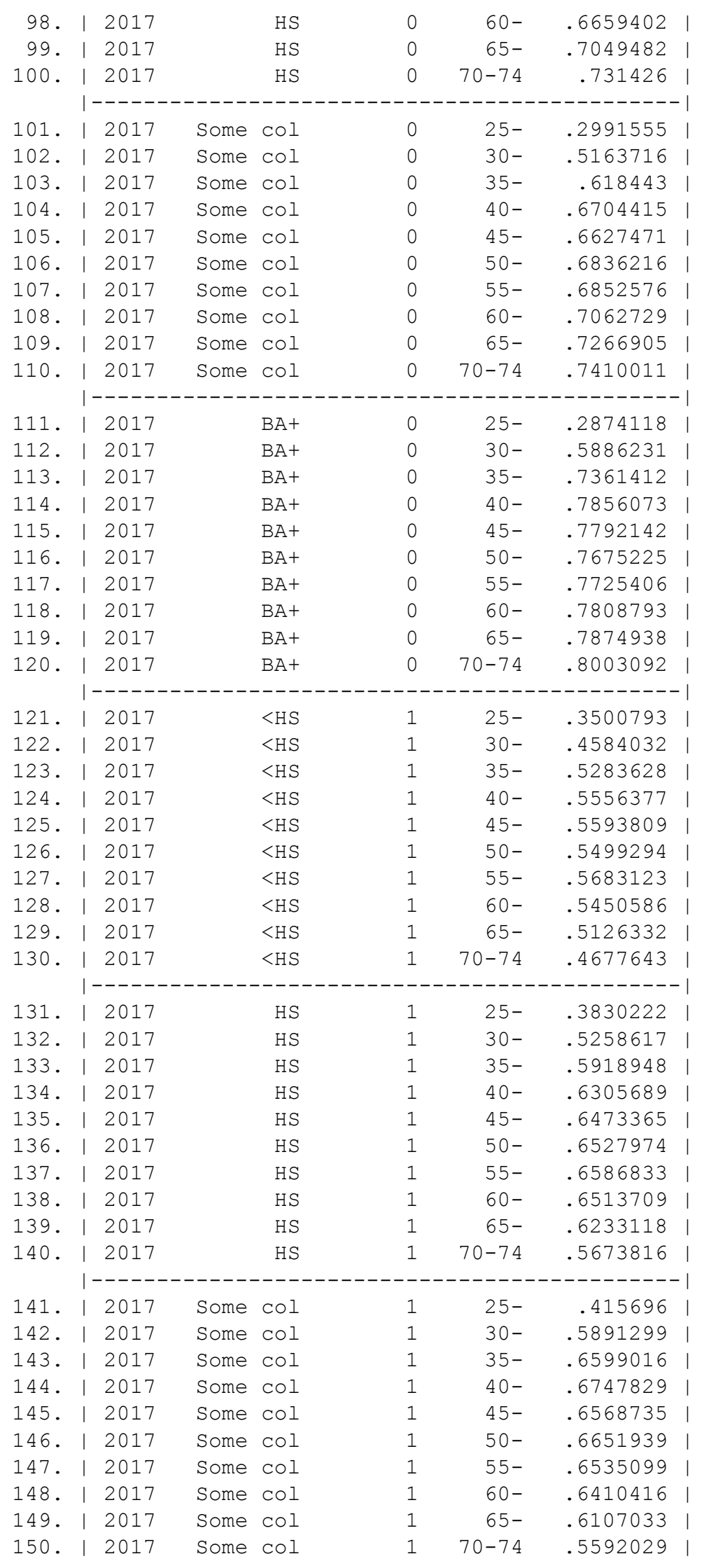




\begin{tabular}{|c|c|c|c|c|c|}
\hline 151. & | 2017 & $\mathrm{BA}+$ & 1 & $25-$ & .3850566 \\
\hline 152. & | 2017 & $\mathrm{BA}+$ & 1 & $30-$ & .6593518 \\
\hline 153. & | 2017 & $\mathrm{BA}+$ & 1 & $35-$ & .7521486 \\
\hline 154. & | 2017 & $\mathrm{BA}+$ & 1 & $40-$ & .7633536 \\
\hline 155. & | 2017 & $\mathrm{BA}+$ & 1 & $45-$ & .7473819 \\
\hline 156. & | 2017 & $\mathrm{BA}+$ & 1 & $50-$ & .7256068 \\
\hline 157. & | 2017 & $\mathrm{BA}+$ & 1 & $55-$ & .7118468 \\
\hline 158. & | 2017 & $\mathrm{BA}+$ & 1 & $60-$ & .6886373 \\
\hline 159. & | 2017 & $\mathrm{BA}+$ & 1 & 65- & .6477264 \\
\hline 160. & | 2017 & $\mathrm{BA}+$ & 1 & $70-74$ & .6025909 \\
\hline
\end{tabular}


Table A2

Married and single death rates (per 10,000), and marriage mortality ratio, by race/ethnicity year, sex, and age

White

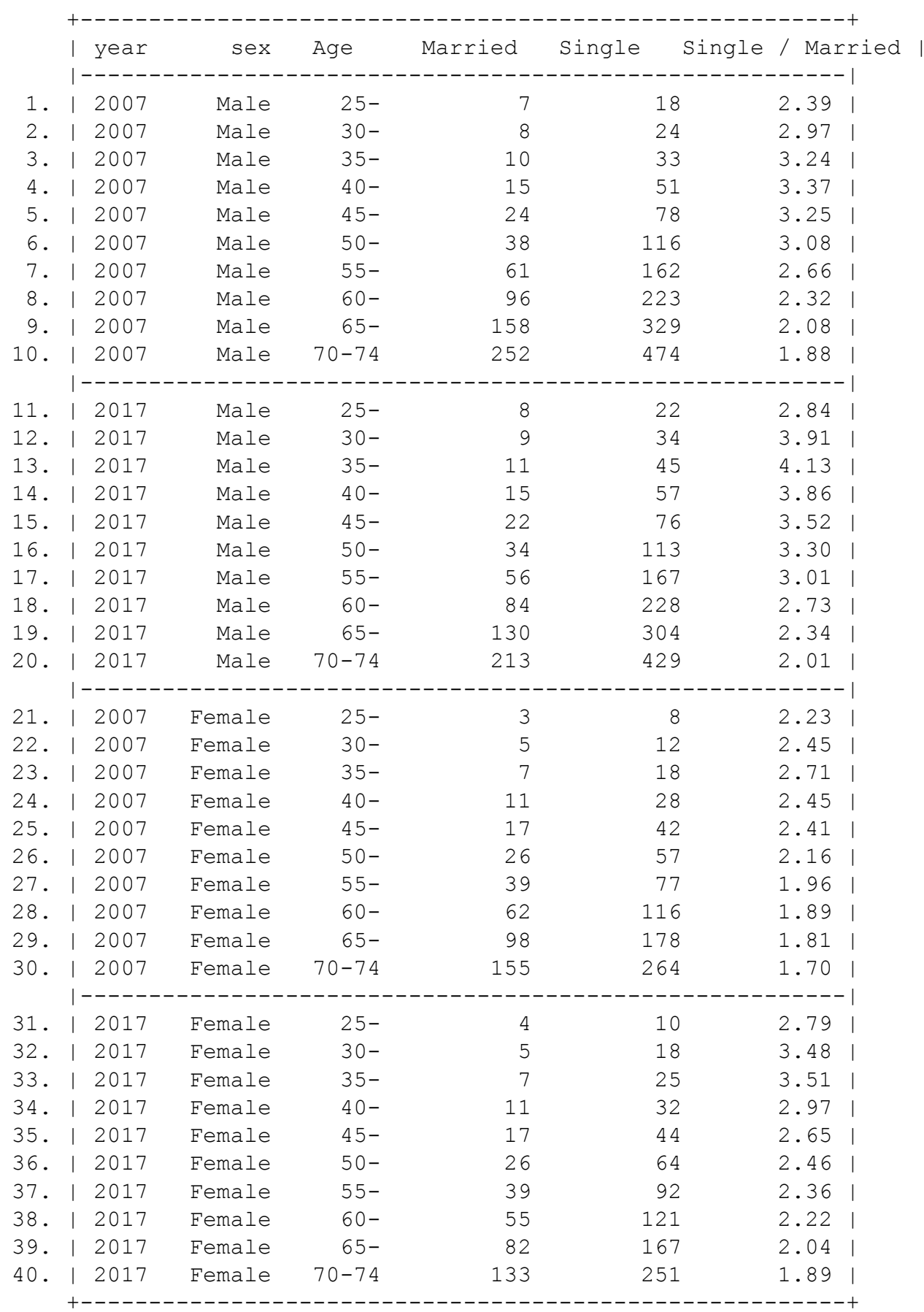


Hispanic

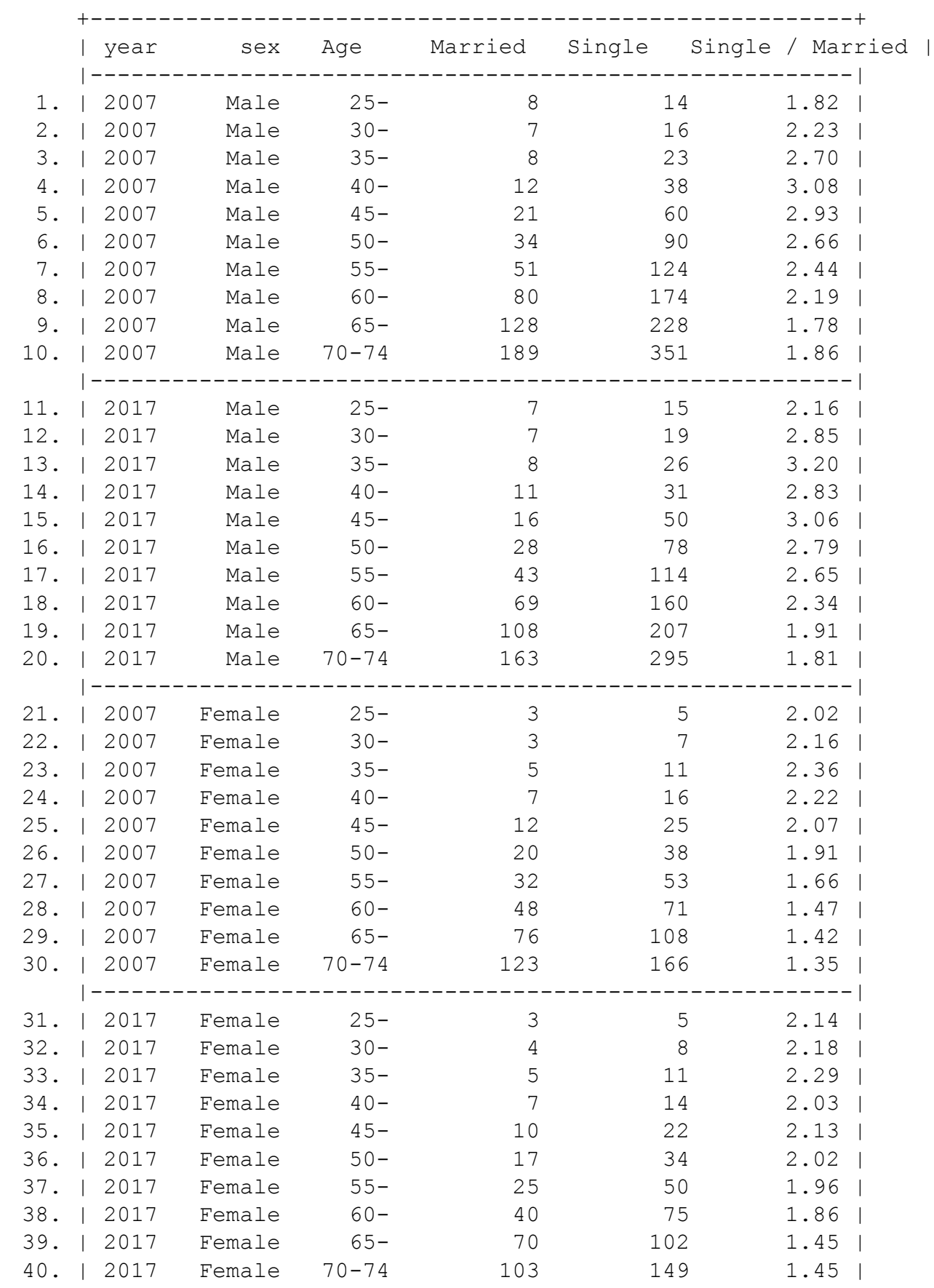


Black

\begin{tabular}{|c|c|c|c|c|c|c|}
\hline & I year & sex & Age & Married & Single single & / Married \\
\hline & & & & & & $------\mid$ \\
\hline 1 . & | 2007 & Male & $25-$ & 15 & 29 & 1.91 \\
\hline 2 . & | 2007 & Male & $30-$ & 17 & 35 & 2.06 \\
\hline 3. & | 2007 & Male & $35-$ & 19 & 47 & 2.45 \\
\hline 4 . & | 2007 & Male & $40-$ & 26 & 64 & $2.50 \quad$ \\
\hline 5 . & | 2007 & Male & $45-$ & 41 & 100 & 2.47 \\
\hline 6 . & 2007 & Male & $50-$ & 75 & 160 & 2.14 \\
\hline 7 . & 2007 & Male & $55-$ & 116 & 229 & $1.97 \mid$ \\
\hline 8 . & 2007 & Male & $60-$ & 171 & 308 & 1.80 \\
\hline 9. & | 2007 & Male & $65-$ & 249 & 419 & $1.68 \mid$ \\
\hline \multirow[t]{2}{*}{10.} & | 2007 & Male & $70-74$ & 363 & 531 & $1.46 \mid$ \\
\hline & $\mid------$ & ----- & ------- & ---- & ---- & $------\mid$ \\
\hline 11. & | 2017 & Male & 25- & 15 & 30 & 2.00 \\
\hline 12 . & | 2017 & Male & $30-$ & 15 & 37 & 2.41 \\
\hline 13. & | 2017 & Male & $35-$ & 20 & 46 & 2.25 \\
\hline 14. & | 2017 & Male & $40-$ & 27 & 56 & $2.08 \quad$ \\
\hline 15. & 2017 & Male & $45-$ & 36 & 83 & 2.32 \\
\hline 16. & | 2017 & Male & $50-$ & 56 & 117 & 2.10 \\
\hline 17. & | 2017 & Male & $55-$ & 88 & 194 & 2.20 \\
\hline 18. & | 2017 & Male & $60-$ & 136 & 265 & 1.95 \\
\hline 19. & | 2017 & Male & 65- & 203 & 366 & 1.80 \\
\hline \multirow[t]{2}{*}{20.} & | 2017 & Male & $70-74$ & 294 & 474 & 1.61 \\
\hline & $\mid-----$ & ------- & ------- & ---- & ---- & $------\mid$ \\
\hline 21. & | 2007 & Female & $25-$ & 7 & 10 & 1.52 \\
\hline 22 . & | 2007 & Female & $30-$ & 9 & 16 & 1.78 \\
\hline 23. & | 2007 & Female & $35-$ & 13 & 24 & 1.85 \\
\hline 24. & | 2007 & Female & $40-$ & 19 & 35 & 1.88 \\
\hline 25 . & | 2007 & Female & $45-$ & 30 & 57 & 1.86 \\
\hline 26 . & | 2007 & Female & $50-$ & 47 & 86 & 1.82 \\
\hline 27 . & 2007 & Female & $55-$ & 70 & 109 & 1.55 \\
\hline 28 . & | 2007 & Female & $60-$ & 95 & 145 & 1.53 । \\
\hline 29. & | 2007 & Female & $65-$ & 144 & 214 & 1.48 \\
\hline \multirow[t]{2}{*}{30 . } & | 2007 & Female & $70-74$ & 205 & 291 & 1.42 \\
\hline & $\mid-----$ & ------- & ------- & ---- & -------- & $------\mid$ \\
\hline 31. & | 2017 & Female & $25-$ & 6 & 11 & 1.90 \\
\hline 32 . & | 2017 & Female & $30-$ & 8 & 15 & 1.88 \\
\hline 33. & | 2017 & Female & $35-$ & 12 & 21 & 1.76 \\
\hline 34. & | 2017 & Female & $40-$ & 17 & 31 & 1.81 \\
\hline 35 . & | 2017 & Female & $45-$ & 26 & 45 & 1.73 \\
\hline 36. & | 2017 & Female & $50-$ & 39 & 70 & 1.81 \\
\hline 37 . & | 2017 & Female & $55-$ & 60 & 108 & 1.82 \\
\hline 38. & | 2017 & Female & $60-$ & 82 & 139 & 1.70 \\
\hline 39. & | 2017 & Female & $65-$ & 115 & 191 & 1.66 \\
\hline 40. & | 2017 & Female & $70-74$ & 164 & 260 & 1.58 \\
\hline
\end{tabular}


Table A3

White married and single death rates (per 10,000), and marriage mortality ratio, by education year, sex, and age

Less than high school

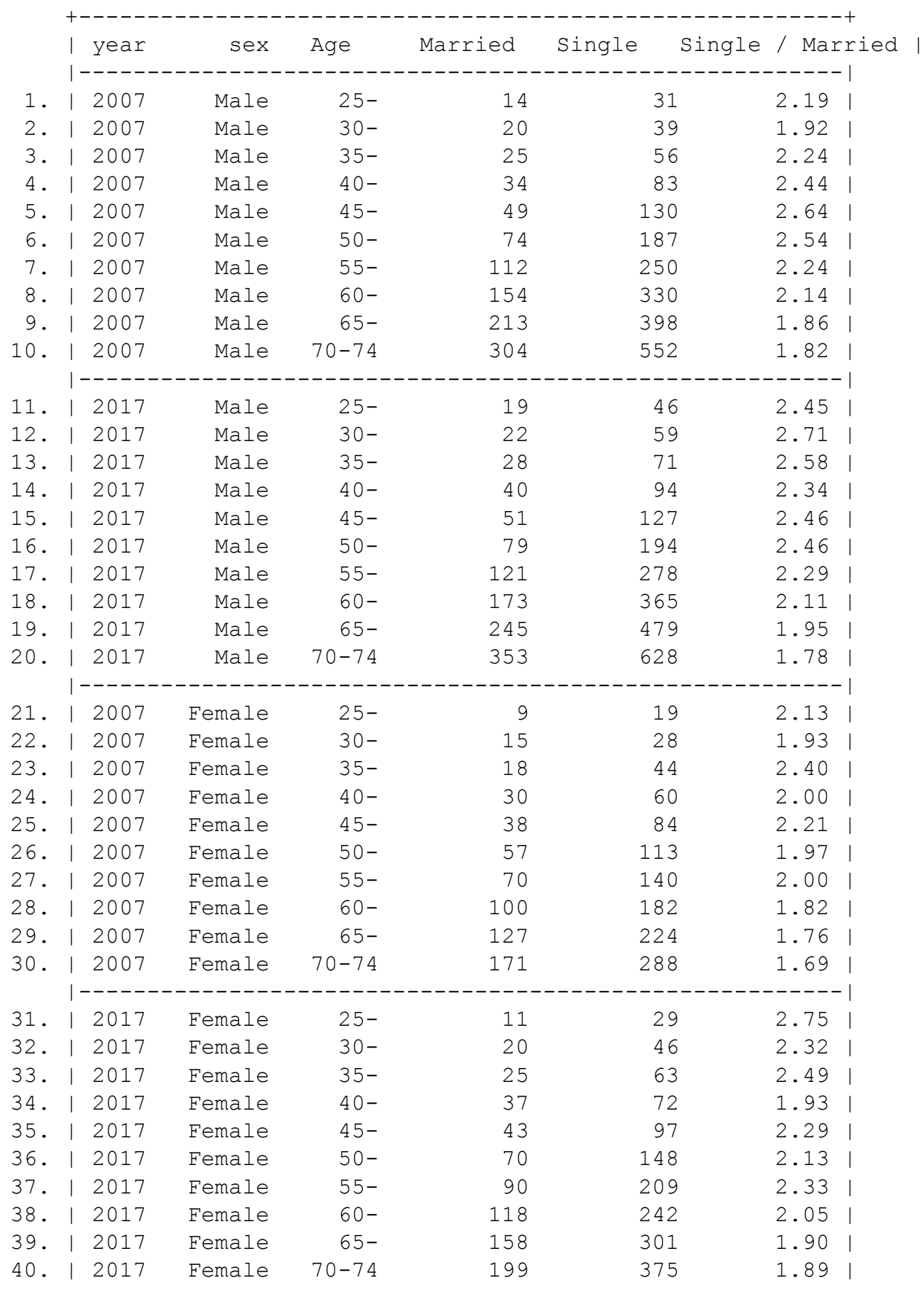


High school

\begin{tabular}{|c|c|c|c|c|c|c|}
\hline & I year & sex & Age & Married & Single single & / Married \\
\hline & $\mid------$ & ------- & ------1 & -------- & ---------------- & $------\mid$ \\
\hline 1. & 2007 & Male & $25-$ & 9 & 22 & 2.44 \\
\hline 2 . & | 2007 & Male & $30-$ & 10 & 31 & $2.94 \mid$ \\
\hline 3. & | 2007 & Male & $35-$ & 14 & 40 & 2.86 \\
\hline 4 . & 2007 & Male & $40-$ & 19 & 58 & 3.05 \\
\hline 5 . & | 2007 & Male & $45-$ & 29 & 86 & 3.031 \\
\hline 6 . & | 2007 & Male & $50-$ & 44 & 135 & $3.04 \quad$ \\
\hline 7 . & | 2007 & Male & $55-$ & 73 & 199 & $2.74 \mid$ \\
\hline 8 . & | 2007 & Male & $60-$ & 111 & 268 & $2.42 \mid$ \\
\hline 9. & 2007 & Male & $65-$ & 172 & 374 & $2.17 \mid$ \\
\hline 10. & 2007 & Male & $70-74$ & 266 & 547 & 2.06 \\
\hline & $\mid-----$ & ------ & ------- & ---- & ---- & $------\mid$ \\
\hline 11. & | 2017 & Male & $25-$ & 11 & 33 & 2.88 \\
\hline 12 . & | 2017 & Male & $30-$ & 14 & 48 & 3.45 \\
\hline 13. & | 2017 & Male & $35-$ & 17 & 57 & 3.42 \\
\hline 14. & | 2017 & Male & $40-$ & 21 & 69 & 3.27 \\
\hline 15. & | 2017 & Male & $45-$ & 30 & 93 & 3.13 \\
\hline 16. & | 2017 & Male & $50-$ & 43 & 127 & 2.94 \\
\hline 17. & | 2017 & Male & $55-$ & 67 & 189 & 2.82 \\
\hline 18. & | 2017 & Male & $60-$ & 100 & 266 & 2.66 \\
\hline 19. & 2017 & Male & 65- & 155 & 378 & 2.44 \\
\hline 20. & | 2017 & Male & $70-74$ & 245 & 511 & 2.09 \\
\hline & $\mid------$ & -------- & ------- & ---- & --------- & $------\mid$ \\
\hline 21 . & | 2007 & Female & 25- & 5 & 10 & 2.23 \\
\hline 22 . & | 2007 & Female & $30-$ & 6 & 16 & 2.57 \\
\hline 23. & 2007 & Female & $35-$ & 9 & 22 & 2.56 \\
\hline 24 . & 2007 & Female & $40-$ & 13 & 32 & 2.43 \\
\hline 25 . & | 2007 & Female & $45-$ & 20 & 48 & 2.46 \\
\hline 26 . & | 2007 & Female & $50-$ & 29 & 65 & 2.24 \\
\hline 27 . & 2007 & Female & $55-$ & 43 & 87 & 2.01 \\
\hline 28 . & 2007 & Female & $60-$ & 64 & 125 & 1.96 \\
\hline 29. & 2007 & Female & 65- & 99 & 192 & 1.93 \\
\hline 30 . & | 2007 & Female & $70-74$ & 156 & 272 & 1.75 \\
\hline & $\mid-----$ & -------- & ------- & ---- & ---- & $------\mid$ \\
\hline 31. & | 2017 & Female & $25-$ & 6 & 18 & 2.93 \\
\hline 32 . & | 2017 & Female & $30-$ & 9 & 29 & 3.24 \\
\hline 33. & | 2017 & Female & $35-$ & 12 & 37 & 3.08 \\
\hline 34. & 2017 & Female & $40-$ & 16 & 44 & 2.73 \\
\hline 35 . & | 2017 & Female & $45-$ & 23 & 59 & 2.56 \\
\hline 36. & | 2017 & Female & $50-$ & 32 & 77 & 2.39 \\
\hline 37 . & | 2017 & Female & $55-$ & 46 & 108 & 2.33 \\
\hline 38 . & | 2017 & Female & $60-$ & 65 & 142 & 2.20 \\
\hline 39. & | 2017 & Female & 65- & 91 & 193 & 2.11 \\
\hline 40. & | 2017 & Female & $70-74$ & 145 & 274 & $1.89 \mid$ \\
\hline
\end{tabular}




\section{Some college}

\begin{tabular}{|c|c|c|c|c|c|c|}
\hline & I year & sex & Age & Married & Single single & / Married \\
\hline & & & & & & $------\mid$ \\
\hline 1 . & | 2007 & Male & $25-$ & 6 & 15 & 2.39 \\
\hline 2 . & | 2007 & Male & $30-$ & 7 & 21 & $2.95 \mid$ \\
\hline 3 . & | 2007 & Male & $35-$ & 9 & 27 & 2.92 \\
\hline 4 . & | 2007 & Male & $40-$ & 14 & 39 & $2.79 \quad$ \\
\hline 5 . & | 2007 & Male & $45-$ & 23 & 58 & $2.54 \mid$ \\
\hline 6 . & 2007 & Male & $50-$ & 39 & 93 & $2.39 \mid$ \\
\hline 7 . & 2007 & Male & $55-$ & 63 & 129 & 2.05 \\
\hline 8 . & | 2007 & Male & $60-$ & 101 & 169 & $1.68 \mid$ \\
\hline 9. & | 2007 & Male & $65-$ & 165 & 259 & $1.57 \mid$ \\
\hline \multirow[t]{2}{*}{10.} & | 2007 & Male & $70-74$ & 265 & 359 & $1.35 \mid$ \\
\hline & $\mid------$ & ----- & ------- & ---- & ----- & $------\mid$ \\
\hline 11. & | 2017 & Male & $25-$ & 8 & 22 & 2.82 \\
\hline 12 . & | 2017 & Male & $30-$ & 10 & 34 & 3.46 \\
\hline 13. & | 2017 & Male & $35-$ & 12 & 41 & 3.40 \\
\hline 14. & | 2017 & Male & $40-$ & 16 & 51 & 3.13 । \\
\hline 15. & | 2017 & Male & $45-$ & 24 & 62 & $2.59 \mid$ \\
\hline 16. & | 2017 & Male & $50-$ & 36 & 95 & 2.64 \\
\hline 17. & | 2017 & Male & $55-$ & 61 & 136 & 2.22 \\
\hline 18. & | 2017 & Male & $60-$ & 94 & 188 & 2.00 \\
\hline 19. & | 2017 & Male & 65- & 156 & 267 & 1.71 \\
\hline \multirow[t]{2}{*}{20.} & | 2017 & Male & $70-74$ & 256 & 359 & 1.40 \\
\hline & $\mid-----$ & ------- & ------- & ---- & ---- & $------\mid$ \\
\hline 21. & | 2007 & Female & $25-$ & 3 & 7 & $2.38 \mid$ \\
\hline 22 . & | 2007 & Female & $30-$ & 5 & 10 & 2.21 \\
\hline 23. & | 2007 & Female & $35-$ & 7 & 16 & 2.25 \\
\hline 24 . & 2007 & Female & $40-$ & 11 & 22 & 2.04 \\
\hline 25 . & | 2007 & Female & $45-$ & 17 & 33 & 1.93 \\
\hline 26 . & | 2007 & Female & $50-$ & 25 & 49 & 1.94 \\
\hline 27 . & 2007 & Female & $55-$ & 41 & 68 & 1.64 \\
\hline 28 . & | 2007 & Female & $60-$ & 64 & 102 & 1.59 । \\
\hline 29. & | 2007 & Female & 65- & 98 & 146 & 1.48 \\
\hline \multirow[t]{2}{*}{30 . } & | 2007 & Female & $70-74$ & 153 & 221 & 1.45 \\
\hline & $\mid-----$ & ------- & ------- & ------- & -------- & $------\mid$ \\
\hline 31. & | 2017 & Female & $25-$ & 4 & 11 & 2.85 \\
\hline 32 . & | 2017 & Female & $30-$ & 6 & 18 & 2.82 \\
\hline 33. & | 2017 & Female & $35-$ & 9 & 24 & 2.72 \\
\hline 34. & | 2017 & Female & $40-$ & 12 & 31 & $2.51 \mid$ \\
\hline 35 . & | 2017 & Female & $45-$ & 20 & 39 & 1.98 \\
\hline 36 . & | 2017 & Female & $50-$ & 28 & 58 & 2.07 \\
\hline 37 . & | 2017 & Female & $55-$ & 42 & 80 & 1.90 \\
\hline 38. & | 2017 & Female & $60-$ & 58 & 109 & 1.90 \\
\hline 39. & | 2017 & Female & $65-$ & 94 & 160 & 1.70 \\
\hline 40. & | 2017 & Female & $70-74$ & 151 & 243 & 1.61 \\
\hline
\end{tabular}


BA or higher

\begin{tabular}{|c|c|c|c|c|c|c|}
\hline & I year & $\operatorname{sex}$ & Age & Married & Single single & / Married \\
\hline & $\mid------$ & ------- & ------1 & ---------1 & ----------------1 & $------\mid$ \\
\hline 1. & 2007 & Male & $25-$ & 3 & 6 & 2.28 \\
\hline 2 . & | 2007 & Male & $30-$ & 3 & 8 & $2.39 \mid$ \\
\hline 3. & | 2007 & Male & $35-$ & 4 & 13 & 3.18 \\
\hline 4 . & 2007 & Male & $40-$ & 6 & 21 & 3.18 \\
\hline 5 . & | 2007 & Male & $45-$ & 11 & 31 & $2.78 \quad$ \\
\hline 6. & | 2007 & Male & $50-$ & 19 & 49 & $2.50 \quad$ \\
\hline 7 . & | 2007 & Male & $55-$ & 35 & 80 & $2.32 \mid$ \\
\hline 8 . & | 2007 & Male & $60-$ & 55 & 113 & $2.04 \quad$ \\
\hline 9. & 2007 & Male & $65-$ & 92 & 175 & 1.89 \\
\hline 10. & 2007 & Male & $70-74$ & 163 & 268 & 1.65 \\
\hline & $\mid-----$ & ------ & ------- & ---- & ---- & $------\mid$ \\
\hline 11. & | 2017 & Male & $25-$ & 2 & 6 & $2.61 \mid$ \\
\hline 12 . & | 2017 & Male & $30-$ & 3 & 11 & $3.48 \quad$ \\
\hline 13. & | 2017 & Male & $35-$ & 4 & 17 & 3.79 \\
\hline 14. & 2017 & Male & $40-$ & 7 & 24 & $3.61 \mid$ \\
\hline 15. & | 2017 & Male & $45-$ & 10 & 33 & 3.19 \\
\hline 16. & | 2017 & Male & $50-$ & 17 & 49 & 2.85 \\
\hline 17. & | 2017 & Male & $55-$ & 28 & 74 & $2.68 \quad$ \\
\hline 18. & | 2017 & Male & $60-$ & 46 & 115 & $2.51 \mid$ \\
\hline 19. & 2017 & Male & $65-$ & 78 & 164 & 2.10 \\
\hline 20. & | 2017 & Male & $70-74$ & 136 & 262 & $1.93 \mid$ \\
\hline & $\mid------$ & ------- & ------- & --------1 & -------------- & $------\mid$ \\
\hline 21. & | 2007 & Female & $25-$ & 1 & 3 & $2.39 \mid$ \\
\hline 22 . & 2007 & Female & $30-$ & 2 & 4 & 2.00 \\
\hline 23. & 2007 & Female & $35-$ & 3 & 7 & 2.10 \\
\hline 24 . & 2007 & Female & $40-$ & 6 & 12 & 2.09 \\
\hline 25 . & | 2007 & Female & $45-$ & 9 & 20 & 2.23 \\
\hline 26 . & | 2007 & Female & $50-$ & 15 & 28 & 1.89 \\
\hline 27 . & 2007 & Female & $55-$ & 22 & 41 & 1.83 \\
\hline 28 . & | 2007 & Female & $60-$ & 35 & 62 & 1.80 \\
\hline 29. & | 2007 & Female & 65- & 59 & 97 & 1.63 । \\
\hline 30 . & | 2007 & Female & $70-74$ & 103 & 167 & 1.61 \\
\hline & $\mid-----$ & ------- & ------- & ---- & ---- & $------\mid$ \\
\hline 31. & | 2017 & Female & $25-$ & 1 & 3 & 1.99 \\
\hline 32 . & | 2017 & Female & $30-$ & 2 & 6 & 2.82 \\
\hline 33. & | 2017 & Female & $35-$ & 3 & 9 & 2.80 \\
\hline 34. & 2017 & Female & $40-$ & 5 & 13 & 2.46 \\
\hline 35 . & | 2017 & Female & $45-$ & 8 & 20 & 2.44 \\
\hline 36. & | 2017 & Female & $50-$ & 13 & 28 & 2.10 \\
\hline 37. & | 2017 & Female & $55-$ & 21 & 45 & 2.15 \\
\hline 38. & | 2017 & Female & $60-$ & 31 & 65 & 2.08 \\
\hline 39. & | 2017 & Female & $65-$ & 49 & 93 & 1.90 \\
\hline 40. & | 2017 & Female & $70-74$ & 82 & 148 & 1.80 \\
\hline
\end{tabular}

